\title{
Formal Taxonomic Treatment of Cyanophytes
}

\author{
RALPH A. LEWIN \\ Scripps Institution of Oceanography, A.002 University of California, La Jolla, California 92093
}

\begin{abstract}
Exception is taken to the classification of cyanophytes as bacteria. The fact that cyanophytes can now be grown in pure culture does not necessarily mean that their nomenclature should be dealt with by the Bacteriological Code, which, contrary to the Botanical Code, permits viable, pure cultures to serve as representatives of type strains, or that consequently they are bacteria. The question of the true nature of cyanophytes (i.e., bacterial or algal) should be discussed by both botanists and microbiologists, and the matter should perhaps be referred to the International Union of Biological Sciences for a ruling.
\end{abstract}

In a recent paper (14) on the taxonomic position of cyanophytes, Stanier wrote: "Their traditional classification as algae was...based on the resemblances between the cyanophytan cell and one constituent of the algal cell, its chloroplast." This is not really so. As correctly pointed out earlier (16), cyanophytes are generally classified with other plants, including eucaryotic algae, because they carry out photosynthesis with a plant-type chlorophyll and have the ability to evolve oxygen when illuminated. It may be argued that in eucaryotic algae these pigments are formed in plastids which can be regarded as symbiotic organisms descended from some postulated primeval photosynthetic procaryotes. However, this hypothesis, though briefly proposed in the last century and forming the main subject of a thesis presented by Mereshkovsky in 1905 (a German version [10], with the author's name transliterated as "Mereschkowsky," was published in 1930), was not generally accepted or even considered testable until after the autonomy of Euglena plastids had been demonstrated experimentally (11) and until further evidence for Mereshkovsky's "symbiogenesis" had been collected and extensively discussed by Margulis (9).

According to Stanier (14), the "news" that cyanophytes are really bacteria was not generally known but is now spreading. This is not strictly correct, either. It is not news, but an assertion based on a novel interpretation of the word "bacteria," which has generally been used to include various procaryotes in a class parallel to, but not embracing, the cyanophytes as defined above (13). As recounted by Stanier and van Niel (18), bacteria and cyanophytes were associated in a special taxon, the Schizophyta, over 100 years ago (4), but it was not until 1937 that Chatton introduced the term "procaryotic" (3). Later, in view of the growing corpus of information from electron microscopy, etc.,
Stanier and van Niel (18) proposed the name Prokaryota for all microbes of that kind, and this is now generally accepted. Nevertheless, it would be illogical to assert that, because $A$ and $B$ are both subsets of $C, A$ is therefore a subset of $B$.

The taxonomy of the Cyanophyceae is admittedly in a deplorable state today, largely because botanists have classified these organisms on the basis of their phenotypic characters which, as expressed in nature, do not necessarily reflect their genotypes. Thanks to the excellent recent work of Stanier and Cohen-Bazire and their colleagues $(12,15)$, using pure cultures grown under controlled conditions, this situation is now being remedied by the use of characteristics, largely physiological, like those which are being successfully employed for the taxonomy of bacteria and various small eucaryotes such as yeasts and Chlorella $(5,8)$. The taxonomy of microbial plants, including fungi and algae, will be made more meaningful if and when the proposal to consider viable cultures as valid types is formally accepted $(1,7)$. But this is not to say that all such organisms should necessarily be dealt with according to the International Code of Nomenclature of Bacteria, as has been recently proposed (17). The advisability of such an expedient is debatable, to say the least. Its adoption would mean, almost inevitably, that in the future cyanophytes would have to be considered according to two somewhat different codes, since there is little doubt that botanists (who now, as hitherto, have been most concerned with these organisms as algae) would continue to include them within the scope of the Botanical Code. (A similar situation already confuses the taxonomy of many groups of flagellates which can be classified either as plants or as animals.) Before getting into such a morass, we should discuss the subject in the respective purviews of both the botanists and the microbiologists, and per- 
haps appeal for (and abide by) rulings from the International Union of Biological Sciences, as suggested for such cases by Buchanan et al. (2). I submit that such matters should not be decided unilaterally, as Stanier et al. (17) suggest.

According to Principle 4 in the International Code of Nomenclature of Bacteria (6), "The primary purpose of giving a name to a taxon is to supply a means of referring to it rather than to indicate the characters or the history of the taxon." This is to say that formally accepted names like Cyanophyceae, Actinomycetales, and Mycetozoa are not to be lightly changed or discarded, whatever they may originally have implied about the color, shape, or nature of such algae, bacteria, or animals. Names like "Cyanobacteria" and "Actinobacteria" have been used recently, but I do not think that thay have been formally approved and legitimized.

\section{LITERATURE CITED}

1. Buchanan, R. E. 1961. Living types. Taxon 10:129-131.

2. Buchanan, R. E., T. Wiken, S. T. Cowan, and W. A. Clark (ed.). 1958. Preface to the International Code of Nomenclature of Bacteria and Viruses. Iowa State University Press, Ames.

3. Chatton, E. 1937. Titres et Travaux Scientifiques. Sète, Sottano.

4. Cohn, F. 1875. Untersuchungen ueber Bakterien. Beitr. Biol. Pflanz. 1:141-207.

5. Kessler, E. 1978. Physiological and biochemical contributions to the taxonomy of the genus Chlorella. Microbiology 119:13-16.

6. Lapage, S. P., P. H. A. Sneath, E. F. Lessel, V. B. D. Skerman, H. P. R. Seeliger, and W. A. Clark. 1975. International code of nomenclature of bacteria. American Society for Microbiology, Washington, D. C.
7. Lewin, R. A., and G. E. Fogg. 1978. Typification of microorganisms: a proposal. Taxon 27:121.

8. Lodder, J., and N. Kreger-Van Rij. 1970. The yeasts: a taxonomic study. North Holland Publishing Co., Amsterdam.

9. Margulis, L. 1970. Origin of eukaryotic cells. Yale University Press, New Haven.

10. Mereschkowsky, C. 1910. Theorie der zwei Plasmaarten als Grundlage der Symbiogenesis, einer neuen Lehre von der Entstehung der Organismen. Biol. Zentralbl. 30:278-303, 321-347, 353-367.

11. Pringsheim, E. G., and O. Pringsheim. 1952. Experimental elimination of chromatophores and eye-spot in Euglena gracilis. New Phytol. 51:65-76.

12. Rippka, R., J. Desruelles, J. B. Waterbury, M. Herdman, and R. Y. Stanier. 1979. Generic assignments, strain histories and properties of pure cultures of cyanobacteria. J. Gen. Microbiol. 111:1-61.

13. Stanier, R. Y. 1974. Division I: the cyanobacteria, p. 22. In R. E. Buchanan and N. E. Gibbons (ed.), Bergey's manual of determinative bacteriology, 8 th ed. The Williams \& Wilkins Co., Baltimore.

14. Stanier, R. Y. 1977. The position of cyanobacteria in the world of phototrophs. Carlsberg Res. Commun. 42:7798.

15. Stanier, R. Y., and G. Cohen-Bazire. 1977. Phototrophic prokaryotes: the cyanobacteria. Annu. Rev. Microbiol. 31:225-274.

16. Stanier, R. Y., M. Doudoroff, and E. Adelberg. 1963. The microbial world, 2nd ed. Prentice-Hall, Inc., Englewood Cliffs, N.J.

17. Stanier, R. Y., W. R. Sistrom, T. A. Hansen, B. A. Whitton, R. W. Castenholz, N. Pfennig, V. N. Gorlenko, E. N. Kondratieva, K. E. Eimhjellen, R. Whittenbury, R. L. Gherna, and H. G. Triiper. 1978. Proposal to place the nomenclature of the cyanobacteria (blue-green algae) under the rules of the International Code of Nomenclature of Bacteria. Int. J. Syst. Bacteriol. 28:335-336.

18. Stanier, R. Y., and C. B. van Niel. 1941. The main outlines of bacterial classification. J. Bacteriol. 42:437466 . 